\title{
The Economic Effects of Removing Barriers to Trade in Telecommunications and
}

\section{Financial Services}

\author{
George Verikios and Xiao-guang Zhang* \\ Productivity Commission, Locked Bag 2, Collins Street East, Melbourne, Australia 8003. \\ Paper presented to the Fourth Annual Conference on Global Economic Analysis,
}

West Lafayette, USA, June 27-29, 2001.

\begin{abstract}
This paper quantifies the impact on the economies of the world of complete liberalisation of trade in two key services sectors, telecommunications and financial services, using a global general equilibrium model. The paper uses new estimates of these barriers for telecommunications and financial services. The results indicate that completely liberalising trade in telecommunications and financial services would benefit the world as a whole. Although the distribution of gains among regions is not even, most regions are projected to gain from the liberalisation. In general, the regions with the highest barriers benefit most. The analysis demonstrates that commercial presence of foreign firms via foreign direct investment is an important mode of delivering telecommunications and financial services.
\end{abstract}

\section{$1 \quad$ Introduction}

Trade in services is a rapidly growing area of international trade. Since the General Agreement on Trade in Services (GATS) was reached in 1993, progress has been made in opening up multilateral trade in a few key services sectors. In most countries, however, barriers to trade in many services still exist, which implies that potentially large gains can be expected from further liberalisation. However, the impact of multilateral liberalisation of trade in services, especially individual services sectors, on the regions and economies of the world has yet to be rigorously assessed (The Secretariat of the Council for Trade in Services 1999). This study provides a quantitative analysis of liberalising trade in two key services sector, telecommunications and financial services, for which World Trade Organization (WTO) members have already undertaken scheduled commitments for liberalisation. Recent studies have indicated that despite the agreement reached most WTO members have committed only to partial liberalisation of trade in telecommunications and financial services (The Secretariat of the Council for Trade in Services, 1998a, 1998b). By quantifying the effects of complete liberalisation in telecommunications and financial services, this study is intended to provide impetus to WTO members for further commitments to liberalising trade in these sectors.

This study uses a computable general equilibrium (CGE) approach. A number of previous studies have attempted to quantify the effects of liberalising services trade in a similar framework. ${ }^{1}$ A recent study

\footnotetext{
* The views expressed in this paper are those of the authors and do not necessarily reflect those of the Productivity Commission. The authors thank Kevin Hanslow for helpful advice on the construction of the database used in this study. The authors also thank Philippa Dee, Patrick Jomini, Richard Snape and Lynne Williams for helpful comments and advice on an earlier version of this paper.
} 
(Dee and Hanslow 2000) uses a three-sector multi-region CGE model with international trade and investment, FTAP, to quantify the effects of removing barriers to trade in an aggregate services sector. It finds that liberalisation of trade in services leads to a gain of around \$US136 billion or 0.46 per cent of world real gross national product (GNP). The largest gains are projected to go to the regions with the highest services trade barriers and the regions with the lowest services trade barriers are projected to experience smaller gains or losses.

This study extends Dee and Hanslow (2000) to focus on two individual sectors: telecommunications and financial services. The FTAP model is modified accordingly to suit the special characteristics of these two sectors. This study also uses two recent studies (Warren, 1999 and Kalirajan et al., 1999) on barrier estimates for these two sectors. As the database used reflects the full implementation of the Uruguay Round of multilateral trade negotiations (UR), this study quantifies the effects of removing barriers to trade in telecommunications and financial services in a post-UR setting.

Services are different in nature from goods. Goods can be transported and consumed away from their producer. The consumers of many services, however, cannot be easily separated, geographically, from their producers. This distinctive nature requires a broad definition of trade in services. The GATS sets out a comprehensive definition of trade in services in terms of four different modes of delivery: (i) crossborder supply; (ii) consumption abroad; (iii) commercial presence in the consuming country; and (iv) the presence of natural persons (WTO Secretariat, 1999). This definition is used in this study as well as in Dee and Hanslow (2000).

For many economies, cross-border supply and commercial presence are important modes of supplying foreign telecommunications and financial services. In the mid-1990s the share of cross-border supply in world output of telecommunications and financial services was 5.9 and 3.4 per cent respectively, compared with 1.0 and 1.7 per cent, respectively, for commercial presence. ${ }^{2}$ The apparent low share of commercial presence in some consuming regions is most likely a result of restrictions currently in place. There is great potential for expanding trade in telecommunications and financial services through increased commercial presence and market shares of foreign service suppliers, when trade barriers in this sector are removed.

The paper is organised as follows. Section 2 outlines the analytical framework. Section 3 discusses the model database and its construction. The projected effects of trade liberalisation in telecommunications and financial services are presented and discussed in sections 4 and 5, respectively, while section 6 summarises the policy implications of this study and indicates avenues for future research.

\footnotetext{
${ }^{1}$ For example, see Brown et al. (1995), Petri (1997), Hertel (1999) Markusen, Rutherford and Tarr (1999) and McKibbin (1999). Most of these are somewhat limited in their approach to modelling trade in services. Brown et al. (1995) and McKibbin (1999) model foreign portfolio, rather than direct, investment in services, one of the key vehicles by which services are traded internationally. Petri (1997) liberalises trade in goods and FDI in services, but uses barrier data that is outdated. Hertel (1999) liberalises cross-border trade only, not FDI. Markusen, Rutherford and Tarr (1999) only model FDI in services that are used as intermediate inputs into production, not for final demand.

2 Estimates from the FTAP2 database.
} 
The model used in this study is referred to as FTAP2, which is a modified version of the FTAP model applied in Dee and Hanslow (2000). FTAP2 is documented in detail in Verikios and Zhang (2001) and implemented using the GEMPACK software suite (Harrison and Pearson 1996).

Three economic agents are distinguished in each region: firms, a representative household and a government sector. The household owns all primary factors of production: land, natural resources, capital and labour. The supplies of land and natural resources are fixed in the primary industries sector within each region. Labour is mobile among sectors but not between regions. Capital is the only internationally mobile factor.

Firms purchase primary factor services from the household and use them to produce goods and services. Each host region has two types of firms: domestic firms and foreign affiliates. Thus, firms are identified by location (sector and host region) and by ownership (home region). Foreign affiliates combine their home region's capital with the host region's labour, land and natural resources to produce goods and services for the host region's users and exports.

As in FTAP, commercial presence of foreign suppliers in FTAP2 is represented by foreign affiliates. In each sector of a region, goods or services may be produced by domestic firms and foreign affiliates simultaneously. Like domestic firms, foreign affiliates have their own cost structure for intermediate inputs and primary factors. They also have their own local sales and exports. Foreign affiliates compete with local firms and with each other, not only in the host region's domestic markets but also in foreign markets for their exports.

Firms are assumed to source capital from their home regions and other factors of production from host regions. Given input prices and output demands, firms are assumed to select a combination of inputs to minimise the costs of production. As capital is internationally mobile and other factors of production are immobile across regions, firms are able to minimise costs of production by allocating productive activities across regions. Within a given sector, firms can potentially locate production in any host region. The exact location or commercial presence of a firm, however, is determined by the supply of capital in the home region and the demand for output in the host region.

\subsection{Supply of capital}

Commercial presence of foreign affiliates in host regions is driven by the capital owner's desire to maximise the return on capital. Figure 1 shows how capital owned by a region is allocated to firms across sectors and regions. Each region has a given endowment of wealth. The wealth owner, the representative household, is assumed to maximise returns by allocating wealth across sectors and regions. Wealth is composed of equity in productive assets and net foreign debt. Equity is made up of land, natural resources and physical capital. Of these three, only capital is mobile. With net foreign debt fixed as a share of income, the allocation of wealth essentially involves deciding on the allocation of capital across sectors and regions. 


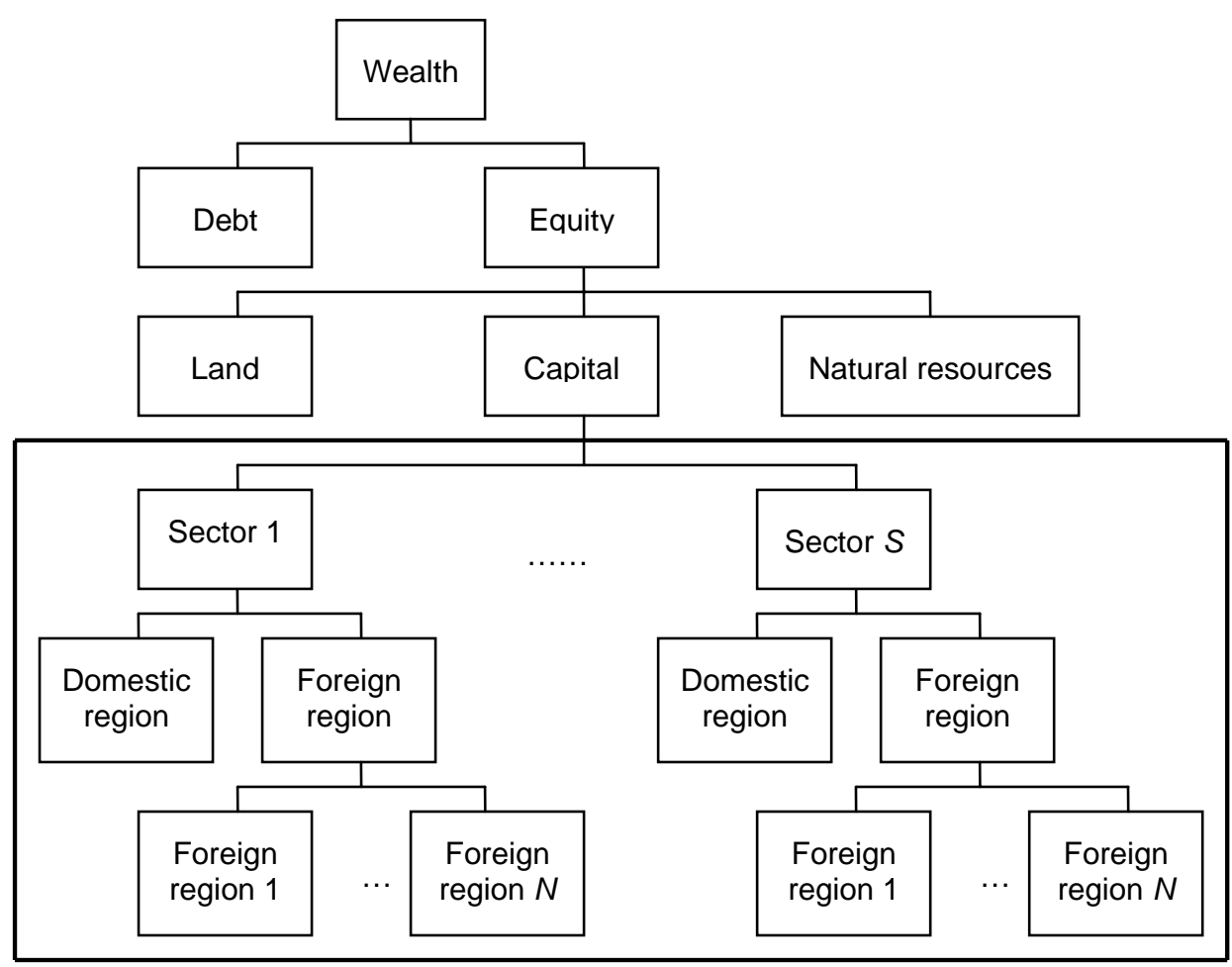

Source: Modified from figure 2.3 of Hanslow, Phamduc and Verikios (1999).

Capital can be allocated to home firms in any sector. Within each sector, capital can be allocated to domestic firms or affiliates located in foreign regions. The returns to capital for each home region are maximised when the expected rates of return to all capital owned by that region, and used by all firms located at home or abroad, are equalised. The enclosed area in figure 2 indicates the location of these firms.

The capital allocation process ensures that, in the absence of barriers to capital mobility, the expected rates of return to capital used by firms from the same home region are equalised, but not for firms from different home regions. Therefore, in long-run equilibrium firms from the same home region will pay an equal return per unit of capital input to the capital owner. In the presence of barriers to capital mobility, firms operating in restricted sectors or regions will transfer rents in addition to the normal return, from their customers to the capital owner.

In the model, wealth owned by a region may not be equal to its equity in productive assets, due to its foreign debt or credit position. As the current analysis is comparative static in nature, no repayment of existing debt is allowed. It is therefore assumed that the shares of foreign debt in government and household incomes for each region are fixed and stable over time. Foreign debts are serviced only by paying interest at an internationally fixed rate.

\subsection{Demand for firm-specific products}

The products of domestically owned firms and foreign affiliates located in the same region are assumed to be imperfect substitutes. Consumers in each region are assumed to maximise utility by selecting a particular bundle of differentiated goods and services to suit their needs. The cost minimisation process 
of firms gives rise to intermediate demands for goods and services. As foreign affiliates compete with domestic firms in the same region, the demand for a given good or service determines the location or commercial presence of foreign affiliates. The demand structure of the model is similar to FTAP, and is represented in figure 2.

Figure 2 Structure of demand for firm-specific products by host region

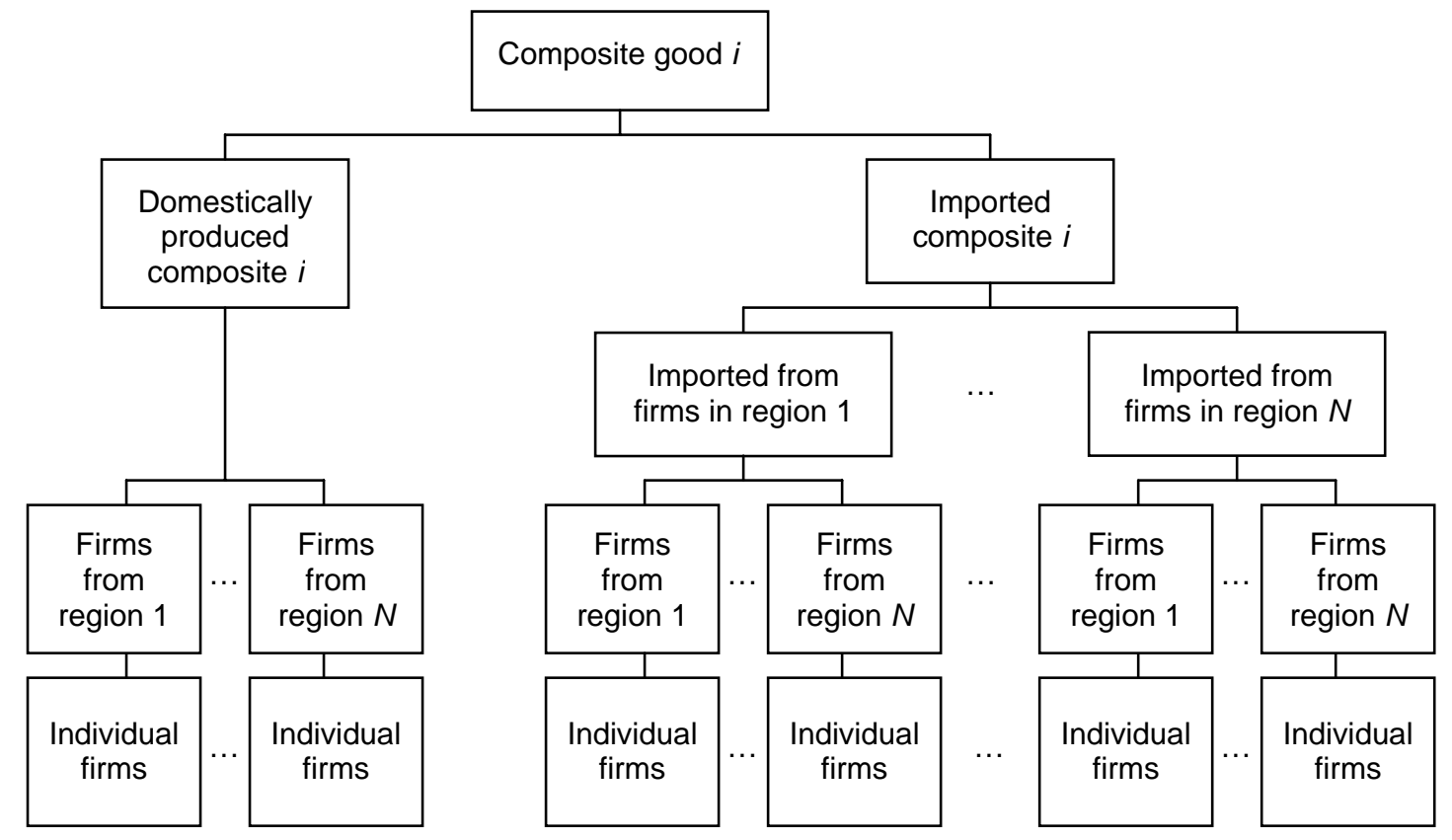

Source: Adapted from figure 2.2 of Hanslow, Phamduc and Verikios (1999).

At the top node of the constant elasticity of supply nest in figure 2, the consumer can choose between composite goods from domestic or foreign locations. At the second node, the consumer can also choose composite imports from a particular source region. At the third node of the nesting, the consumer can choose a domestically produced good produced by a foreign affiliate or by a domestically owned firm. The consumer can also choose an imported good produced by a firm located in any other region.

The bottom node of the nesting in figure 2 shows that goods produced by each firm in either the domestic region or foreign regions, is a composite of all the varieties of individual firms within that group. This implies firm-level product differentiation associated with large-group monopolistic competition as developed by Francois, McDonald and Nordstrom (1996). With such firm-level product differentiation, the consumers of each region can benefit from having more varieties to choose from, as it is more likely for them to find a product or service which best suits their particular needs. This increased choice is modelled as a gain in product variety for consumers in each region.

The values for the elasticities used for the first and second nodes of the demand nesting are discussed in the next section. The values used for the elasticity of substitution between goods produced by firms from different regions but located in the same region is 7.5. The values used for the elasticity of substitution between different firm types (level four in figure 2) is set at 15, which is the same as in the initial implementation of FTAP. 


\subsection{Cross-border supply of services}

FTAP2 recognises a fundamental attribute of cross-border supply of financial services and telecommunications that differentiate them from most other goods and services. Normally, imported goods and services are substitutable with their domestically produced counterparts. However, imported financial services or telecommunications are not the same as domestic services. For instance, imported financial services form only a part of international transactions. Imported services have to be combined with domestic services to deliver international financial transactions or international telecommunications to domestic consumers. Allowing substitution between imported and domestic financial and telecommunication services causes imported services to rise at the expense of domestic services if the relative price of imported services falls. This is not consistent with economic reality.

Based on this consideration, the demand elasticity of substitution between domestic and imported financial services and telecommunications is assumed to be zero. For the same reason, financial services and telecommunications imported from different regions are also assumed to be non-substitutable with each other, so these elasticities are also set to zero. However, all other imported and domestically produced varieties of goods and services remain substitutable as in Dee and Hanslow (2000).

Model database

The starting point for the FTAP2 database is a modified version of the one used in Verikios and Hanslow (1999), which fully implements the UR. This database does not contain all the detail to support the theoretical structure of FTAP2. To model and simulate the removal of all barriers to trade in services, the database has been extended to contain information on bilateral FDI stocks by region and sector; FDI rentals by region and sector; and barriers to the establishment and operation of domestic firms and foreign affiliates. This modified database is described in Verikios and Zhang (2001).

The new database provides the same regional breakdown as in Dee and Hanslow (2000) but with greater sectoral detail. It divides the world into 19 regions (see table 1) and each regional economy into eight sectors, six of which are services sectors. They are construction, (wholesale and retail) trade and transport; communications, ${ }^{3}$ finance, insurance and business services, ${ }^{3}$ other services and dwellings. Non-services sectors are aggregated into primary and secondary industries.

\subsection{Bilateral FDI stocks and rentals}

Bilateral FDI stocks at the sectoral level are estimated from APEC (1995), UN (1999) and a wide range of publications by various international organisations as well as individual countries. ${ }^{4}$ The information is based on statistics for the mid-1990s. These sources provide information on total inward and outward FDI stocks by region and broad sectors. With this information, a RAS procedure is used to generate a consistent database of bilateral FDI stocks by region and sector. The resulting inward and outward FDI stocks by region and sector are largely consistent with the three-sector database used in Dee and Hanslow

\footnotetext{
3 Despite these sectors including non-telecommunications and non-financial services (as defined by the GATS) such as postal services and business services, respectively, modelling trade in telecommunications and financial services is generalised to the whole sector as defined in the database. Thus from this point forward, these sectors will be referred to as telecommunications and financial services, respectively.

4 The sources and methods are fully documented in Verikios and Zhang (2001).
} 
(2000), and are summarised in tables 1 and 2. The resulting FDI stocks database reflects the commercial presence of foreign affiliates by origin (home region) and destination (sector of a host region), with a complete input-output structure defined for each foreign affiliate.

Tables 1 and 2 show the sources and destinations of FDI stocks in seven of the eight sectors in the database. ${ }^{5}$ The EU, the USA and Japan were the main sources of FDI, accounting for 36, 23 and 17 per cent of total outward FDI stocks, respectively. Both the EU and the USA were also the main destinations of FDI, receiving about the same amount of FDI as they invested abroad. Unlike the EU and the USA, however, Japan's outward FDI far exceeded its inward FDI. Japan was the source of 83 per cent of total net outward FDI, making it the single most important net FDI exporter in the world. Among developing countries, Indonesia was the largest recipient, receiving 29 per cent of the total net inward FDI stocks. The next most important net FDI importers were Mexico (10 per cent), China (9 per cent) and Malaysia (5 per cent).

The services sectors made up 36 per cent of all FDI stocks, compared with 23 per cent for the primary sector and 41 per cent for the secondary sector. Of the services sectors, the trade and transport sector and financial services sectors had the largest shares with 14 per cent each, and other services accounted for 6 per cent. The telecommunications sector had less than 2 per cent of the total FDI stocks.

Table 3 reports the share of FDI in domestic telecommunications and financial services capital stocks of each host region. The share of FDI was relatively small for both sectors: 0.92 per cent for telecommunications and 1.35 per cent for financial services. Developed regions usually had a larger foreign commercial presence than developing regions. The size of foreign commercial presence was closely correlated with trade barriers, especially barriers that discriminate against foreign firms. The low foreign presence in many developing countries, such as China, was most likely to be the result of high barriers.

The expected rates of return to capital used in FTAP2 are obtained from the modified and updated database from Verikios and Hanslow (1999). FDI rentals are calculated by multiplying FDI stocks by the corresponding rates of return. The FDI rental shares are then used in splitting the host region's sectoral output into production by domestic firms and foreign affiliates.

\footnotetext{
5 The dwellings sector is assumed to have no FDI.
} 


\begin{tabular}{|c|c|c|c|c|c|c|c|c|}
\hline Region & $\operatorname{Pri} i^{\mathbf{a}}$ & $\operatorname{Sec}^{\boldsymbol{b}}$ & $\operatorname{Con}^{c}$ & $T t_{-} \boldsymbol{d}$ & $\mathrm{Cmn} \boldsymbol{e}^{\boldsymbol{e}}$ & $F i b^{\boldsymbol{f}}$ & Osr $g$ & Total \\
\hline Australia & 14,207 & 13,137 & 524 & 12,274 & 627 & 388 & 5,030 & 46,188 \\
\hline New Zealand & 1,700 & 3,134 & 79 & 207 & 138 & 3,576 & 478 & 9,312 \\
\hline Japan & - & 16,230 & 101 & 5,332 & 289 & 61,720 & 4,315 & 87,987 \\
\hline Korea & - & 4,216 & 63 & 218 & 169 & 868 & 1,858 & 7,392 \\
\hline Indonesia & 77,550 & 5,305 & 218 & 537 & 33 & 181 & 434 & 84,258 \\
\hline Malaysia & 6,946 & 7,272 & 608 & 1,545 & 21 & 27 & 292 & 16,711 \\
\hline Philippines & 3,178 & 862 & 20 & 156 & 22 & 397 & 210 & 4,845 \\
\hline Singapore & - & 11,682 & 329 & 2,981 & 42 & 268 & 59 & 15,361 \\
\hline Thailand & 1,550 & 4,002 & 1,227 & 2,024 & 11 & 1,213 & 673 & 10,701 \\
\hline China & 3,902 & 15,557 & 289 & 905 & 2 & 47 & 5,418 & 26,120 \\
\hline Hong Kong & 4,315 & 5,691 & 336 & 3,572 & 916 & 9,127 & 546 & 24,503 \\
\hline Taiwan & - & 11,823 & 12 & 554 & 61 & 268 & 1,218 & 13,937 \\
\hline Canada & 5,610 & 47,006 & 4,104 & 7,503 & 155 & 9,866 & 2,741 & 76,987 \\
\hline USA & 28,899 & 131,977 & 2,215 & 93,630 & 7,153 & 35,393 & 52,637 & 351,905 \\
\hline Mexico & 5,680 & 10,714 & 86 & 6,217 & 225 & 7,918 & 494 & 31,335 \\
\hline Chile & 9,757 & 995 & 52 & 934 & 106 & 107 & 400 & 12,351 \\
\hline Rest Cairns ${ }^{\mathbf{h}}$ & 8,182 & 32,968 & 297 & 5,332 & 523 & 8,342 & 2,286 & 57,931 \\
\hline Europ Union & 148,818 & 222,269 & - & 59,536 & 13,586 & 72,066 & 4,583 & 520,858 \\
\hline Rest of World $\mathbf{i}$ & 47,438 & 109,308 & 2,163 & 23,222 & 29 & 3,479 & 14,405 & 200,044 \\
\hline World & 367,733 & 654,149 & 12,723 & 226,680 & 24,110 & 215,253 & 98,078 & $1,598,726$ \\
\hline
\end{tabular}

Table 2 Outward FDI stocks by home region and sector, 1995 (US\$ million)

\begin{tabular}{|c|c|c|c|c|c|c|c|c|}
\hline Region & $P r i^{a}$ & $\operatorname{Sec}^{\boldsymbol{b}}$ & $\operatorname{Con}^{c}$ & $T t_{-} \boldsymbol{d}$ & $\mathrm{Cmn}^{\boldsymbol{e}}$ & $\operatorname{Fib}^{\boldsymbol{f}}$ & Osr 9 & Total \\
\hline Australia & 9,807 & 6,622 & 550 & 1,293 & 498 & 358 & 2,326 & 21,453 \\
\hline New Zealand & 695 & 1,459 & 82 & 568 & 48 & 110 & 330 & 3,293 \\
\hline Japan & 49,987 & 87,043 & 2,058 & 53,845 & 8,585 & 46,818 & 27,973 & 276,309 \\
\hline Korea & 4,508 & 1,340 & 26 & 178 & 12 & 124 & 104 & 6,292 \\
\hline Indonesia & 217 & 775 & 41 & 261 & 23 & 116 & 89 & 1,523 \\
\hline Malaysia & 247 & 781 & 30 & 369 & - & 5 & 89 & 1,520 \\
\hline Philippines & - & 144 & 12 & 77 & 5 & 41 & 362 & 642 \\
\hline Singapore & 1,797 & 3,933 & 174 & 1,191 & 73 & 869 & 694 & 8,731 \\
\hline Thailand & - & 120 & 25 & 170 & 14 & 124 & 102 & 554 \\
\hline China & 548 & 129 & 49 & 115 & 3 & 29 & 37 & 910 \\
\hline Hong Kong & 6,625 & 14,614 & 289 & 1,829 & 170 & 6,066 & 3,808 & 33,400 \\
\hline Taiwan & 100 & 5,282 & - & 324 & - & 267 & 316 & 6,290 \\
\hline Canada & 12,721 & 33,478 & - & 5,804 & 114 & 11,714 & 7,548 & 71,380 \\
\hline USA & 84,235 & 161,579 & 370 & 50,749 & 5,494 & 58,855 & 5,222 & 366,505 \\
\hline Mexico & 177 & 433 & 21 & 261 & 14 & 138 & 73 & 1,117 \\
\hline Chile & - & 177 & 7 & 51 & 2 & 31 & 30 & 299 \\
\hline Rest Cairns ${ }^{\mathbf{h}}$ & 657 & 1,519 & 72 & 487 & 30 & 293 & 284 & 3,341 \\
\hline Europ Union & 140,863 & 235,818 & 4,160 & 76,714 & 9,001 & 86,049 & 29,642 & 582,246 \\
\hline Rest of World ${ }^{i}$ & 54,548 & 98,904 & 4,755 & 32,395 & 23 & 3,245 & 19,050 & 212,920 \\
\hline World & 367,733 & 654,149 & 12,723 & 226,680 & 24,110 & 215,253 & 98,078 & $1,598,726$ \\
\hline
\end{tabular}

$\mathbf{a}_{\text {Primary industries. }} \mathbf{b}_{\text {Secondary industries. }}{ }^{\mathbf{c}}$ Construction. $\mathbf{d}_{\text {Trade and transport. }} \mathbf{e}_{\text {Telecommunications. }}{ }^{\mathbf{f}}$ Financial services. $\mathbf{g}_{\text {Other services. }}$ $\mathbf{h}$ This region consists of Argentina, Brazil, Colombia and Uruguay. ${ }^{\mathbf{i}}$ This region is almost entirely composed of non-APEC developing countries. ${ }^{-}$Nil.

Source: FTAP2 database. 


\begin{tabular}{|c|c|c|}
\hline Region & Telecommunications & Financial services \\
\hline Australia & 1.33 & 0.38 \\
\hline New Zealand & 1.43 & 9.65 \\
\hline Japan & 0.07 & 1.39 \\
\hline Korea & 0.22 & 0.55 \\
\hline Indonesia & 0.19 & 0.25 \\
\hline Malaysia & 0.12 & 0.18 \\
\hline Philippines & 0.14 & 1.91 \\
\hline Singapore & 0.22 & 1.26 \\
\hline Thailand & 0.03 & 2.26 \\
\hline China & 0.01 & 0.05 \\
\hline Hong Kong & 1.42 & 12.90 \\
\hline Taiwan & 0.20 & 0.42 \\
\hline Canada & 0.27 & 4.62 \\
\hline United States of America & 1.11 & 0.85 \\
\hline Mexico & 0.19 & 4.14 \\
\hline Chile & 0.57 & 0.35 \\
\hline Rest of the Cairns Group & 0.40 & 0.98 \\
\hline European Union & 1.94 & 1.65 \\
\hline Rest of the World ${ }^{\mathbf{a}}$ & 0.02 & 0.37 \\
\hline World & 0.92 & 1.35 \\
\hline
\end{tabular}

$\mathbf{a}$ This region is almost entirely composed of non-APEC developing countries.

Source: FTAP2 database.

\subsection{Barriers to trade in telecommunications and financial services}

The updated database from Verikios and Hanslow (1999) does not contain barriers to trade and foreign investment in services. These have to be injected into the database separately. Estimates of the tax equivalents of these barriers for financial services are taken from Kalirajan et al (1999) and for telecommunications from Warren (1999). These barriers are imposed using the technique of Malcolm (1998). 6

A common effect of any barrier to trade in a service is to reduce the supply of the service and increase the price for users. Following Petri (1997) and Dee and Hanslow (2000), the barriers are represented as both cost-increasing for users and rent-creating for producers. The barriers create rents to factors used in the sector in which trade is restricted. These factors earn supranormal rates of return compared with their counterparts in other unrestricted sectors. More importantly, the barriers also create losses in efficiency for the economy as a whole. Modelling the removal of these barriers then involves removal of these rents. The loss in rents for producers and factor owners in the restricted sector 'pays' for the increase in the real income of factor owners or consumers elsewhere. The economy as a whole gains from improvements in allocative efficiency. ${ }^{7}$

Trade barriers are represented as one of two types of ad valorem tax equivalents: the price of firms' output and the cost of capital used by firms. The former measures barriers affecting ongoing operations

\footnotetext{
6 The detailed procedure is described in section 4.2 of Verikios and Zhang (2001)

${ }^{7}$ An alternative approach is adopted in Hertel et al. (1999) and Hertel (1999), in which the barriers are represented as costincreasing for firms using imported intermediate inputs in which trade is restricted. Removal of trade barriers is assumed to create 'import-augmenting technical change' for firms in a host region, which is equal to the measured tariff equivalent.
} 
of a firm while the latter measures barriers to the establishment of a firm. Domestic firms and foreign affiliates in a host region may face different barriers to ongoing operations and establishment. Thus there are four different tax equivalent estimates for trade barriers in the model database. These tax equivalents for all 19 regions are listed in table 4 . These estimates are representative of barriers which were in place in 1997. Thus, they are used to represent barriers to trade in financial services and telecommunications in a post-UR world economy.

Table $4 \quad$ Estimated tax equivalents of post-UR barriers to trade in telecommunications and financial services (per cent)

\begin{tabular}{|c|c|c|c|c|c|c|c|c|}
\hline \multirow[t]{3}{*}{ Region } & \multicolumn{4}{|c|}{ Telecommunications } & \multicolumn{4}{|c|}{ Financial services } \\
\hline & \multicolumn{2}{|c|}{ Output } & \multicolumn{2}{|c|}{ Capital } & \multicolumn{2}{|c|}{ Output } & \multicolumn{2}{|c|}{ Capital } \\
\hline & Domestic & Foreign & Domestic & Foreign & Domestic & Foreign & Domestic & Foreign \\
\hline Australia & - & - & 1.4 & 1.4 & - & 1.4 & - & 43.3 \\
\hline $\mathrm{NZ}$ & - & - & 1.3 & 1.3 & - & 1.9 & - & 8.5 \\
\hline Japan & - & - & 1.8 & 1.8 & 5.8 & 7.7 & - & 3.0 \\
\hline Korea & 2.5 & 4.9 & 4.8 & 9.2 & 14.9 & 18.6 & - & 80.7 \\
\hline Indonesia & 41.0 & 82.0 & 85.9 & 163.3 & 5.3 & 16.3 & - & 81.0 \\
\hline Malaysia & 5.5 & 11.0 & 3.6 & 15.0 & 6.7 & 24.6 & 41.7 & 97.4 \\
\hline Philippines & 21.4 & 53.5 & - & 50.0 & 3.5 & 13.4 & 24.0 & 109.9 \\
\hline Singapore & 0.8 & 0.8 & 5.5 & 8.1 & 8.0 & 20.4 & - & 62.7 \\
\hline Thailand & 14.0 & 28.0 & 32.7 & 55.8 & - & 7.3 & - & 58.4 \\
\hline China & 50.0 & 100.0 & 339.4 & 678.8 & 14.9 & 24.7 & 60.6 & 140.7 \\
\hline Hong Kong & 0.6 & 0.6 & 3.2 & 3.2 & 2.6 & 4.9 & - & 6.4 \\
\hline Taiwan & 1.3 & 2.1 & 5.8 & 9.3 & 8.6 & 14.7 & - & 48.8 \\
\hline Canada & 0.8 & 2.3 & 1.8 & 6.6 & 0.0 & 2.3 & - & 13.4 \\
\hline USA & 0.2 & 0.2 & - & - & 0.0 & 2.4 & - & 8.1 \\
\hline Mexico & 5.4 & 10.8 & 1.8 & 7.8 & 0.0 & 2.2 & - & 21.8 \\
\hline Chile & 1.3 & 1.3 & 1.0 & 1.0 & 7.7 & 11.3 & 39.0 & 57.4 \\
\hline R. Cairns ${ }^{\mathbf{a}}$ & 2.7 & 6.5 & 11.8 & 15.9 & 0.2 & 9.0 & 8.1 & 33.2 \\
\hline EU & 0.3 & 0.7 & 3.6 & 4.6 & - & 2.3 & - & 12.3 \\
\hline R. World ${ }^{\mathbf{b}}$ & 16.4 & 32.8 & 114.0 & 215.0 & - & 8.2 & 6.4 & 51.5 \\
\hline
\end{tabular}

$\mathbf{a}$ The rest of the Cairns group (Argentina, Brazil, Colombia and Uruguay). ${ }^{\mathbf{b}}$ The rest of the world. This region is almost entirely composed of nonAPEC developing countries. - Nil.

Source: FTAP2 database.

In Dee and Hanslow (2000), additional barriers are imposed on cross-border trade in services. They appear as an export tax and the export tax rates are derived from the importing region's barriers on the output of foreign affiliates. This is done to reflect the assumption that exporting regions receive the rents created by the barriers imposed by importing regions on the output of foreign affiliates. Barriers on cross-border trade in services are not imposed here due to the non-substitutability of domestic and imported telecommunications and financial services.

\section{$4 \quad$ Liberalising trade in telecommunications}

The model described above is used to simulate the economic effects of multilateral trade liberalisation in telecommunications. The results are presented in table 5. The final column of table 5 reports the percentage changes in real GNP, by region and for the world as a whole. The world is projected to gain by about US $\$ 24$ billion, or a 0.1 per cent rise in world real GNP. Complete liberalisation of trade in 
telecommunications leads to a gain for all regions, except Malaysia, Thailand and Mexico. The largest gainers are China, Indonesia, the Philippines and the rest of the world. Smaller gainers include Australia, Japan, Hong Kong and the European Union. This indicates that regions with high barriers tend to benefit more than those with low or no barriers.

Table 5 Sources of changes in real GNP of complete trade liberalisation in telecommunications (US\$ million)

\begin{tabular}{|c|c|c|c|c|c|c|c|}
\hline Region & $\begin{array}{l}\text { Allocative } \\
\text { efficiency }\end{array}$ & $\begin{array}{r}\text { Terms of } \\
\text { trade }^{c}\end{array}$ & $\begin{array}{l}\text { Net capital } \\
\text { endowment }\end{array}$ & $\begin{array}{r}\text { Product } \\
\text { variety }\end{array}$ & $\begin{array}{c}\text { Net FDI } \\
\text { income }\end{array}$ & Row sum & Real GNP \\
\hline Australia & -26 & 269 & -57 & -26 & 43 & 204 & 0.06 \\
\hline $\mathrm{NZ}$ & -6 & 54 & -3 & - & 3 & 48 & 0.09 \\
\hline Japan & -177 & 1751 & -826 & -359 & 1168 & 1559 & 0.04 \\
\hline Korea & 36 & -5 & -13 & 1 & 16 & 35 & 0.01 \\
\hline Indonesia & 1152 & -434 & 1303 & 401 & -1151 & 1258 & 0.70 \\
\hline Malaysia & 17 & -30 & - & -5 & -3 & -22 & -0.03 \\
\hline Philippines & 440 & -189 & 523 & 163 & -475 & 458 & 0.72 \\
\hline Singapore & 3 & 6 & -16 & 4 & 15 & 13 & 0.02 \\
\hline Thailand & 37 & -562 & 60 & 17 & -55 & -502 & -0.35 \\
\hline China & 5575 & -1301 & 354 & 1037 & -343 & 5321 & 0.81 \\
\hline Hong Kong & -45 & 378 & -441 & -123 & 390 & 160 & 0.16 \\
\hline Taiwan & 34 & 13 & -22 & -2 & 20 & 43 & 0.02 \\
\hline Canada & -68 & 124 & -38 & -9 & 33 & 42 & 0.01 \\
\hline USA & -339 & 1386 & -1203 & -298 & 1114 & 662 & 0.01 \\
\hline Mexico & -4 & -166 & 65 & 19 & -56 & -143 & -0.06 \\
\hline Chile & -10 & 32 & -25 & -6 & 16 & 7 & 0.01 \\
\hline R. Cairns ${ }^{\mathbf{a}}$ & -42 & 200 & -10 & -15 & 18 & 151 & 0.02 \\
\hline EU & -347 & 4077 & -717 & -347 & 850 & 3518 & 0.05 \\
\hline R. World ${ }^{\mathbf{b}}$ & 14370 & -5638 & 1898 & 2485 & -1604 & 11502 & 0.39 \\
\hline World & 20600 & -34 & 833 & 2938 & - & 24313 & 0.10 \\
\hline
\end{tabular}

$\mathbf{a}$ The rest of the Cairns group (Argentina, Brazil, Colombia and Uruguay). ${ }^{\mathbf{b}}$ The rest of the world. ${ }^{\mathbf{c}}$ The sum of the terms of trade effects on GNP do not sum exactly to zero due to numerical inaccuracy in solving the model. " Nil.

Source: FTAP2 model projections.

\subsection{Sources of regional gains}

The percentage change in real GNP for each region can be decomposed into various contributing factors. ${ }^{8}$ For analytical convenience, these factors are grouped into five effects: (i) allocative efficiency effects; (ii) terms of trade effects; (iii) net capital endowment effects; (iv) product variety effects; and (v) net FDI income effects. Allocative efficiency effects measure the contribution to GNP changes from changes in resource allocation within and across regions as a result of policy changes. Terms of trade effects measure the contribution from changes in the relative price of exports and imports for a region. Where export prices rise more quickly than import prices, or export prices fall less quickly than import prices, there is a terms of trade gain for that region. The net capital endowment effect refers to the contribution from changes in the rental value of the net capital stock (gross capital minus depreciation) located within a region. The capital stock located within a region is made up of the domestically owned and foreign-owned capital stock. Therefore, this is a measure of a change in a region's productive

\footnotetext{
8 The percentage changes in real GNP are analysed using the GTAP welfare decomposition (Huff and Hertel, 1996) which is modified to account for cross-border capital flows (Hanslow et al., 1999).
} 
capacity. Product variety effects refer to the benefits that the increased variety of a particular good or service may provide for consumers. In the model, an increase in the output of a given sector means more firms and more varieties for consumers to choose from. This bestows a benefit to consumers in that region. Net FDI income effects measures the contribution from changes in three different forms of income for a region: the normal rentals received by the owners of foreign capital from the regions in which the capital is invested; the barrier rents received by the owners of foreign capital and affiliates from the host regions; and the income received or paid on foreign credit or debt by a region.

For the world as a whole, only changes in allocative efficiency, net capital endowments and product variety contribute to the changes in real GNP. These three effects can be referred to as 'income generating' factors. The other effects do not change world total GNP, that is, what constitutes a gain for one region is a loss for other regions. They can therefore be referred to as 'income redistributing' factors. For the world as a whole, whether a policy change is beneficial or not depends on income generating factors rather than income redistribution factors. At the regional level, however, both types of contributing factors are important. The contributions of the five effects to the change in regional and world GNP are presented in table 5. The row sums of the five contributors, listed in the penultimate column, equal the change in real GNP.

For the world as a whole, the single most important contributor is the gain in allocative efficiency. This is primarily the result of the reallocation of capital between regions and the reallocation of capital and labour between sectors within regions. This alone generates around 85 per cent of the estimated total increase in world real GNP. The world also gains from increases in both net capital endowments and product variety.

Despite its positive effect for the world as a whole, the contribution of allocative efficiency to individual regions' GNP may not always be positive. As table 5 shows, the distribution of allocative efficiency gains across regions tends to be in favour of liberalising regions and, sometimes, at the expense of regions that have a more open telecommunications sector. This result may be explained by two subeffects. The first is the allocative efficiency effect derived from changes in the size of all sectors within a region. For liberalising regions these effects tend to be positive overall, as output expansion is normally concentrated in the sectors that are already taxed in net terms. ${ }^{9}$ For relatively liberalised regions these effects tend to be either small negatives or small positives, depending on which sectors expand or contract.

The second important subeffect is derived from changes in the capital stock utilised by each region, and the change in the capital stock utilised by each sector within a region. As capital is taxed in all regions, when capital moves from relatively liberalised regions to liberalising regions the former tend to lose and the latter tend to gain in terms of allocative efficiency.

The first two columns of table 6 reports the relative importance of these two subeffects for all regions. Each subeffect is presented as a percentage of the change in allocative efficiency for each region. These percentages sum to + or -100 depending on whether change in allocative efficiency is negative or positive. Decreases in capital utilisation explain a significant proportion of the overall allocative efficiency losses for most developed or investing regions, including Australia, Japan, Hong Kong, the USA and the EU. On the other hand, changes in output explain a significant proportion of the overall

\footnotetext{
${ }^{9}$ Net taxes refers to the sum of all taxes and subsidies: export, import, output and intermediate input taxes and subsidies.
} 
allocative efficiency effects for other regions, including Korea, Indonesia, Malaysia, the Philippines, Singapore, Taiwan, Mexico, Chile and the rest of the Cairns group. In general, regions attracting more capital tend to experience a gain in allocative efficiency, while regions using less capital tend to experience a loss in allocative efficiency.

Table 6 Decomposition of three effects on real GNP of complete trade liberalisation in telecommunications

Subeffects as a percentage of each main effect

\begin{tabular}{|c|c|c|c|c|c|c|}
\hline \multirow[t]{2}{*}{ Region } & \multicolumn{2}{|c|}{ Allocative efficiency } & \multicolumn{2}{|c|}{ Net capital endowment } & \multicolumn{2}{|c|}{ Net FDI income } \\
\hline & Output & Capital used & $\begin{array}{l}\text { Domestically } \\
\text { owned capital }\end{array}$ & Inward FDI & Net FDI income & FDI rents \\
\hline Australia & -27 & -73 & -63 & -37 & 89 & 11 \\
\hline NZ & -83 & -17 & -54 & -46 & 74 & 26 \\
\hline Japan & 36 & -136 & -96 & -4 & 103 & -3 \\
\hline Korea & 86 & 14 & -172 & 72 & 46 & 54 \\
\hline Indonesia & 40 & 60 & 26 & 74 & -98 & -2 \\
\hline Malaysia & 100 & - & -296 & 196 & -257 & 157 \\
\hline Philippines & 80 & 20 & 20 & 80 & -101 & 1 \\
\hline Singapore & 167 & -67 & -81 & -19 & 127 & -27 \\
\hline Thailand & -157 & 257 & 12 & 88 & -106 & 6 \\
\hline China & 53 & 47 & 25 & 75 & -108 & 8 \\
\hline Hong Kong & - & -100 & -108 & 8 & 104 & -4 \\
\hline Taiwan & 91 & 9 & -81 & -19 & 146 & -46 \\
\hline Canada & -94 & -6 & -60 & -40 & 107 & -7 \\
\hline USA & -41 & -59 & -74 & -26 & 110 & -10 \\
\hline Mexico & -350 & 250 & 15 & 85 & -115 & 15 \\
\hline Chile & -70 & -30 & -31 & -69 & 84 & 16 \\
\hline R. Cairns ${ }^{\mathbf{a}}$ & -240 & 140 & -210 & 110 & 164 & -264 \\
\hline EU & -40 & -60 & -87 & -13 & 88 & 12 \\
\hline R. World $\mathbf{b}$ & 30 & 70 & 63 & 37 & -99 & -1 \\
\hline
\end{tabular}

$\mathbf{a}$ The rest of the Cairns group (Argentina, Brazil, Colombia and Uruguay). ${ }^{\mathbf{b}}$ The rest of the world. ${ }^{-}$Nil.

Source: FTAP2 model projections.

The second column of table 5 shows the contribution of changes in terms of trade to real GNP. In contrast to the effect on real GNP of changes in allocative efficiency, the terms of trade effects tend to transfer real GNP from liberalising regions to relatively liberalised regions. Liberalising regions are expected to experience a worsening terms of trade, while liberalised regions experience an improving terms of trade. This is because the barriers in the liberalising regions raise the price of their exports relative to the price of their imports. When the barriers are removed, the relative price of exports to imports tends to fall in liberalising regions and rise in liberalised regions. This represents a correction of the distortions in the relative prices of exports and imports in all regions.

The net capital endowment effect, shown in the third column of table 5, can be decomposed into two subeffects, the changes in domestically owned capital and inward FDI. When policy changes cause a reallocation of capital from liberalised to liberalising regions, both domestically owned capital and inward FDI tend to increase in the latter and decrease in the former. An expansion in domestically owned capital can be financed by liberalising regions withdrawing their outward FDI. Increased inward FDI in liberalising regions can be financed by liberalised regions reducing their FDI in other regions or their 
own domestic capital. Generally, the effect of this reallocation of capital on real GNP is negative for liberalised regions and positive for liberalising regions.

The columns 3 and 4 of table 6 reports the relative importance of these two subeffects in determining the overall net capital endowment effect for all regions. Of all the regions experiencing an overall gain in net capital endowments, the rest of the world is the only one in which the gain is not dominated by increased FDI. It is likely that this is due to intra-regional FDI being counted as domestic capital in this region. Generally, the loss in domestic capital dominates the loss in net capital endowments in relatively liberalised regions.

The fourth column of table 5 shows the contribution of product variety. With capital being the only factor mobile among regions, the change in regional GDP is reflected largely in the change in regional capital endowments. Given the general trend of capital reallocation from liberalised to liberalising regions, GDP normally falls in the former and rises in the latter. This has a direct impact on product variety in those regions, as an increase in the output of a given sector means more firms and more varieties for consumers to choose from. As a result, the product variety effect tends to reinforce the gains or losses that a region experiences in its real GDP due to capital reallocation.

The contribution of the net FDI income effect to regional real GNP, shown in the fifth column of table 5, depends on whether the region concerned is a net FDI supplier or recipient initially, and also whether it has positive or negative net foreign debt. This effect can also be decomposed into two subeffects: the effect of net FDI income and the effect of net FDI rents and debt services. The relative importance of these two subeffects is reported in table 6. Of these two subeffects, net FDI income is more important than net FDI rents and debt services for all regions except the rest of the Cairns group. A net FDI supplier benefits from increased FDI income due to increased outward FDI, but loses the FDI rents created by the barriers to FDI. Furthermore, if regional GNP rises, then net foreign debt may also expand to maintain a fixed debt-income ratio. If a region has an increase in its net foreign debt (a net borrower), interest payments will rise. The overall benefit for an investing and borrowing region is the return from FDI net of lost FDI rents and increased interest payments on new debt.

The opposite is true for a region that is both a net FDI recipient and a net lender. As trade liberalisation reallocates capital assets from liberalised to liberalising regions, the net FDI income effect moves in the opposite direction to the capital flows. Table 6 confirms this by showing that net FDI income flows from liberalising to liberalised regions, with negative net FDI income effects for former and positive net FDI income effects for the latter. Table 6 also indicates that FDI rents and debt service are not a significant source of gains or losses for most regions.

\subsection{Sectoral effects}

The projected effects on sectoral output of completely removing barriers to trade in telecommunications are reported in table 7. As expected, the regions with the highest barriers to trade in telecommunications experience the biggest expansion in telecommunications output. These regions include, among others, China, Indonesia and the rest of the world. The rapid expansion of telecommunications output is due to the large increase in the commercial presence of domestic and foreign firms in these regions. Telecommunications output for the world is projected to increase by 1.73 per cent. The expansion of output occurs through increased output of domestic firms and foreign affiliates in almost all regions. On 
the demand side, the fall in the price of telecommunications relative to other goods and services encourages consumers to switch from other goods and services to telecommunications. Furthermore, as GNP rises in liberalising regions, the demand for all goods and services rises, as evidenced by the significant rise in consumption expenditure in real terms in those regions.

The effects on the output of other sectors can be explained by the changes in resource allocation. That is, as liberalisation causes telecommunications output to rise, this is generally accompanied by a reduction in the output of other sectors, as resources shift from the latter to the former. If the barriers removed are substantial, a region can attract more foreign capital to enlarge its total capital endowment, and the output of its own other sectors may not fall at all. This is the case with the Philippines. More often than not, however, the expansion of telecommunications output is accompanied by reductions in the output of at least some other sectors for most regions.

Table $7 \quad$ Projected effects on sectoral output of complete trade liberalisation in telecommunications (per cent)

\begin{tabular}{|c|c|c|c|c|c|c|c|c|}
\hline Region & $P r i a$ & $\operatorname{Sec}^{\boldsymbol{b}}$ & Con $c$ & $T t_{-} \boldsymbol{d}$ & $\mathrm{Cmn}^{\boldsymbol{e}}$ & $F i b^{f}$ & Osrg & $D w e^{h}$ \\
\hline Australia & 0.56 & -0.55 & -0.46 & -0.11 & 0.08 & -0.03 & 0.03 & -0.05 \\
\hline $\mathrm{NZ}$ & 0.89 & -0.60 & -0.43 & -0.21 & 0.03 & -0.04 & 0.03 & 0.00 \\
\hline Japan & 0.12 & -0.10 & -0.36 & 0.03 & 0.17 & -0.03 & -0.01 & 0.03 \\
\hline Korea & 0.07 & 0.08 & -0.49 & -0.06 & 1.19 & -0.07 & -0.04 & -0.16 \\
\hline Indonesia & 0.21 & 2.50 & 3.31 & 1.39 & 13.59 & 0.85 & -0.29 & 1.08 \\
\hline Malaysia & 0.22 & -0.10 & -0.41 & -0.37 & 1.33 & -0.06 & 0.00 & -0.16 \\
\hline Philippines & 0.74 & 4.50 & 1.10 & 2.19 & 5.37 & 0.71 & 0.69 & 0.58 \\
\hline Singapore & 1.72 & 0.15 & -0.40 & -0.67 & 0.33 & -0.08 & 0.19 & -0.37 \\
\hline Thailand & 0.69 & -0.56 & -0.53 & 0.02 & 6.95 & 0.07 & -0.33 & -0.53 \\
\hline China & -0.43 & 1.02 & 3.12 & 0.34 & 13.78 & 0.58 & -0.11 & 0.41 \\
\hline Hong Kong & -0.31 & -1.31 & -1.99 & -0.24 & -0.20 & -0.47 & -0.40 & -0.44 \\
\hline Taiwan & 0.15 & 0.03 & -0.54 & -0.17 & 0.84 & -0.01 & 0.00 & -0.14 \\
\hline Canada & 0.46 & -0.08 & -0.50 & -0.06 & 0.48 & -0.04 & -0.01 & -0.12 \\
\hline USA & 0.35 & -0.11 & -0.44 & -0.03 & 0.11 & -0.03 & 0.03 & -0.04 \\
\hline Mexico & 0.18 & 0.30 & -2.27 & -0.26 & 1.54 & -0.13 & -0.22 & 0.01 \\
\hline Chile & 0.46 & -0.41 & -1.03 & -0.09 & 0.23 & -0.04 & -0.04 & -0.06 \\
\hline R. Cairns ${ }^{i}$ & 0.32 & -0.12 & -1.03 & 0.02 & 2.12 & -0.05 & -0.08 & -0.13 \\
\hline EU & 0.35 & -0.17 & -0.32 & -0.01 & 0.60 & -0.04 & 0.00 & -0.07 \\
\hline R. Worldj & -0.40 & 0.78 & 2.44 & 0.19 & 11.36 & 0.39 & -0.27 & -0.67 \\
\hline World & 0.09 & 0.05 & 0.03 & 0.02 & 1.73 & 0.00 & -0.03 & -0.12 \\
\hline
\end{tabular}

The impact of removing barriers to trade in telecommunications on other sectors of an economy also depends on the changes in the relative rates of return to factors which are either mobile or immobile between regions. When capital moves from liberalised regions to liberalising regions, the expected rate of return to capital rises in the former relative to that in the latter. Thus the rate of return on capital, relative to immobile factors of production, rises in liberalised regions and falls in liberalising regions. In response to these changes in relative factor returns, firms in liberalised regions tend to demand more labour and other immobile factors and less capital in order to minimise their production costs, while firms in liberalising regions tend to demand more capital and less labour and other immobile factors. As a result, the sectors intensive in the use of immobile factors of production are encouraged to expand more 
rapidly in liberalised regions, while the sectors intensive in the use of capital expand more rapidly in liberalising regions. For example, primary industries in Australia, Japan, the USA and the EU all experience strong growth relative to other sectors. In contrast, secondary industries in Indonesia, the Philippines and China all experience strong growth relative to other sectors.

For the world as a whole, the primary sector has the second highest rate of expansion in output, following the telecommunications sector. In fact, there are only three regions not experiencing an expansion in their primary sectors under the liberalisation of telecommunications: China, Hong Kong and the rest of the world. In general, the expansion in the primary sector tends to be larger in liberalised regions than in liberalising regions. Furthermore, in some liberalised regions the primary sector has the highest output growth rate of all sectors (Australia, New Zealand, Singapore, the USA and the EU). Whereas in liberalising regions the primary sector generally has one of the lowest growth rates among all sectors, if not the lowest.

The differences in primary output expansion among regions can be explained by the special features of the primary sector, as well as the changes in the rates of return to factors. The primary sector is the only sector that uses the sector-specific factors of production, land and natural resources. As the supply of land and natural resources is fixed at the sectoral level within regions, when capital endowments fall in liberalised regions and rise in liberalising regions, the return to (and rental cost of) land and natural resources tends to rise in the former and fall in the latter. This occurs as output and demand for all factors falls in liberalised regions and rises in liberalising regions. The immobility of land and natural resources means that primary producers must fully pass on the changes in primary factor costs to users, regardless of any change in the rental costs of other factors, such as capital and labour. As a result, the price of primary goods falls more in liberalised regions than in liberalising regions. The demand for the primary exports of liberalised regions increases, as the demand in liberalising regions for primary goods shifts from domestically produced goods to imports. On the other hand, in liberalised regions, the demand shifts from imports to domestically produced primary goods. An interesting general equilibrium result seems to be that liberalising trade in a service sector tends to cause an expansionary effect on the production of primary goods in other relatively liberalised regions, and boosts their exports of primary goods to liberalising regions.

\section{$5 \quad$ Liberalising trade in financial services}

Table 8 reports the percentage changes in regional and world real GNP brought about by multilateral liberalisation of financial services. Complete liberalisation of financial services is expected to generate a gain in the world real GDP of US\$23 billion, or 0.09 per cent. Complete liberalisation of financial services tends to benefit liberalising regions more than liberalised regions. Overall, most economies are expected to gain from complete liberalisation of trade in financial services. The biggest winners are South-East Asian and Latin American economies. The USA and Canada are the only two countries projected to be slightly worse off.

\subsection{Sources of regional gains}

The most important contributor to the global gain is the increase in net capital endowments, which accounts for about 63 per cent of the projected change in world real GNP. Liberalising financial services leads to large flows of FDI across regions, and this seems to be influenced by two things. Firstly, all 
regions have barriers to foreign firms in financial services, especially barriers to firm establishment or capital mobility. Secondly, foreign affiliates have a high penetration of domestic financial services markets prior to liberalisation. As a result, financial services liberalisation causes a large proportion of the world capital stock to be reallocated across regions. Therefore, the gains from this capital reallocation, measured as the contribution of net capital endowments, dominate the world real GNP gain.

Table 8 Sources of changes in real GNP of complete trade liberalisation in financial services (US\$ million)

\begin{tabular}{|c|c|c|c|c|c|c|c|}
\hline Region & $\begin{array}{l}\text { Allocative } \\
\text { efficiency }\end{array}$ & $\begin{array}{r}\text { Terms of } \\
\text { trade }^{c}\end{array}$ & $\begin{array}{l}\text { Net capital } \\
\text { endowment }\end{array}$ & $\begin{array}{r}\text { Product } \\
\text { variety }\end{array}$ & $\begin{array}{c}\text { Net FDI } \\
\text { income }\end{array}$ & Row sum & Real GNP \\
\hline Australia & 2 & 126 & 14 & 1 & 11 & 154 & 0.05 \\
\hline $\mathrm{NZ}$ & 117 & -15 & 210 & 66 & -158 & 218 & 0.40 \\
\hline Japan & -2672 & 1348 & -4618 & -2350 & 8592 & 354 & 0.01 \\
\hline Korea & 796 & -578 & 1826 & 663 & -1229 & 1468 & 0.36 \\
\hline Indonesia & 753 & -340 & 2245 & 549 & -1943 & 1250 & 0.70 \\
\hline Malaysia & 262 & -112 & 150 & 70 & -144 & 226 & 0.27 \\
\hline Philippines & 796 & -820 & 1146 & 331 & -853 & 591 & 0.93 \\
\hline Singapore & 326 & -259 & 460 & 205 & -290 & 440 & 0.73 \\
\hline Thailand & 703 & -266 & 2311 & 453 & -1797 & 1396 & 0.96 \\
\hline China & 1221 & -1157 & 104 & 322 & -106 & 384 & 0.06 \\
\hline Hong Kong & -1 & 340 & -260 & -87 & 281 & 275 & 0.27 \\
\hline Taiwan & 88 & -188 & 240 & 82 & -151 & 71 & 0.03 \\
\hline Canada & 22 & -108 & 31 & -10 & 27 & -38 & -0.01 \\
\hline USA & -1511 & 1794 & -5720 & -1555 & 5887 & -1091 & -0.02 \\
\hline Mexico & 1004 & -540 & 3249 & 719 & -2718 & 1701 & 0.69 \\
\hline Chile & 178 & -96 & 142 & 37 & -124 & 136 & 0.24 \\
\hline R. Cairns ${ }^{\mathrm{i}}$ & 3092 & -749 & 11839 & 2839 & -10296 & 6625 & 0.70 \\
\hline $\mathrm{EU}$ & -1529 & 1775 & -3880 & -1749 & 8739 & 3375 & 0.05 \\
\hline R. World & 2817 & -172 & 4676 & 1527 & -3728 & 5108 & 0.17 \\
\hline World & 6463 & -16 & 14164 & 2112 & 0 & 22640 & 0.09 \\
\hline
\end{tabular}

$\mathbf{a}$ This region consists of Argentina, Brazil, Colombia and Uruguay. ${ }^{\mathbf{b}}$ This region is almost entirely composed of non-APEC developing countries.

c The sum of the terms of trade effects on GNP do not sum exactly to zero due to numerical inaccuracy in solving the model. ${ }^{-}$Nil.

Source: FTAP2 model projections.

Gains in allocative efficiency (US\$6 billion) and product variety (US\$2 billion) contribute 29 and 9 per cent of the changes in world real GNP, respectively. The distribution of allocative efficiency gains across regions tends to favour liberalising regions at the expense of the major liberalised regions, such as Japan, the USA and the EU.

Table 9 reports the relative importance of two subeffects on allocative efficiency for all regions, similar to table 6 in section 4. The table shows that the large relatively liberalised regions (Japan, the USA and the EU) experience a decline in allocative efficiency due to a fall in their domestic capital usage, with Japan and the USA experiencing a loss in allocative efficiency due to changes in output as well. The EU experiences a gain in allocative efficiency from changes in output, but this gain is not great enough to offset the loss from reduced capital usage. By contrast, all liberalising regions experience a gain in allocative efficiency from increased capital usage, due largely to the inflow of FDI. Combined with a gain from increased output, they experience an overall gain in allocative efficiency.

The terms of trade effects of financial services liberalisation transfer real income from liberalising to liberalised regions. Liberalising regions experience a worsening of their terms of trade, while liberalised 
regions experience an improvement in their terms of trade. This is because the barriers in liberalising regions restrict the supply of financial services and raise the price of exports relative to the price of imports. When the barriers are removed, the relative price of exports to imports tends to fall in liberalising regions and rise in liberalised regions, dissipating barrier rents flowing from the former to the latter.

Table 9

\section{Decomposition of three effects on real GNP of complete trade liberalisation in financial services}

Subeffects as a percentage of each main effect

\begin{tabular}{|c|c|c|c|c|c|c|}
\hline \multirow[t]{2}{*}{ Region } & \multicolumn{2}{|c|}{ Allocative efficiency } & \multicolumn{2}{|c|}{ Net capital endowment } & \multicolumn{2}{|c|}{ Net FDI income } \\
\hline & Output & Capital used & $\begin{array}{l}\text { Domestically } \\
\text { owned capital }\end{array}$ & Inward FDI & $\begin{array}{l}\text { Net FDI } \\
\text { income }\end{array}$ & $\begin{array}{l}\text { FDI rents \& } \\
\text { debt service }\end{array}$ \\
\hline Australia & 0 & 100 & -898 & 998 & -202 & 302 \\
\hline New Zealand & 42 & 58 & 19 & 81 & -136 & 36 \\
\hline Japan & -48 & -52 & -137 & 37 & 105 & -5 \\
\hline Korea & 75 & 25 & 35 & 65 & -120 & 20 \\
\hline Indonesia & 30 & 70 & 25 & 75 & -101 & 1 \\
\hline Malaysia & 66 & 34 & 20 & 80 & -107 & 7 \\
\hline Philippines & 72 & 28 & 28 & 72 & -110 & 10 \\
\hline Singapore & 71 & 29 & 25 & 75 & -117 & 17 \\
\hline Thailand & 64 & 36 & 29 & 71 & -106 & 6 \\
\hline China & 48 & 52 & -28 & 128 & -190 & 90 \\
\hline Hong Kong & 2990 & -3090 & -320 & 220 & 67 & 33 \\
\hline Taiwan & 71 & 29 & -18 & 118 & -114 & 14 \\
\hline Canada & 127 & -27 & -1714 & 1614 & 33 & 67 \\
\hline United States of America & -32 & -68 & -131 & 31 & 117 & -17 \\
\hline Mexico & 60 & 40 & 19 & 81 & -109 & 9 \\
\hline Chile & 32 & 68 & -2 & 102 & -117 & 17 \\
\hline Rest of Cairns Group ${ }^{\mathbf{a}}$ & 52 & 48 & 23 & 77 & -106 & 6 \\
\hline European Union & 10 & -110 & -169 & 69 & 107 & -7 \\
\hline Rest of the World $\mathbf{b}$ & 61 & 39 & 31 & 69 & -108 & 8 \\
\hline
\end{tabular}

$\mathbf{a}_{\text {This region consists of Argentina, Brazil, Colombia and Uruguay. }}{ }^{\mathbf{b}}$ This region is almost entirely composed of non-APEC developing countries. ${ }^{-}$Nil.

Source: FTAP2 model projections.

The net capital endowment effect reflects the change in the use of capital in each region. Financial services liberalisation increases FDI for all regions as all regions have some discriminatory barriers to the establishment and ongoing operations of foreign affiliates. The removal of these barriers provides an incentive for inward FDI in all regions. Thus, whether or not a region experiences an overall gain in net capital endowments is determined by what happens to domestic capital. The increase in total FDI worldwide is driven, in the main, by the large liberalised regions (Japan, the USA and the EU). Their outward FDI is financed from their domestic capital stocks. In the case of these three regions, the reduction in their domestic capital is significant enough to outweigh the positive effect of increased inward FDI, thus causing an overall fall in their net capital endowments with a negative effect on their real GNP. On the other hand, liberalising regions experience no such a negative effect. Instead, their domestic capital stocks increase, along with inward FDI, because removing their relatively high nondiscriminatory barriers encourages expansion in domestically owned capital as well.

As with telecommunications liberalisation, product variety is positively correlated with changes in net capital endowments due to the effects on GDP of increased endowments. As a result, the product variety 
effect tends to reinforce the gains or losses that a region experiences in net capital endowments. By contrast, the net FDI income effect is inversely correlated with changes in net capital endowments, as inward FDI creates a stream of FDI rental payments for the host country and a stream of FDI income receipts for the home country.

The USA and Canada are the only economies that are not projected to benefit from financial services trade liberalisation. The USA has significant commercial presence in many regions in which there are substantial barriers in place before liberalisation. The USA therefore benefits from other regions' trade barriers in the forms of rents earned by its foreign affiliates. When other regions liberalise their financial services sectors, the USA benefits from increased FDI income from liberalising regions, but loses rents as well as net capital endowments and output. As the world largest investor, the losses exceed the gains marginally, resulting in a small fall in real GNP.

\section{$5.2 \quad$ Sectoral effects}

The projected effects of complete liberalisation of trade in financial services on sectoral output in all regions are presented in table 9 . World output of financial services is projected to increase by 0.6 per cent, which is the largest increase experienced by any sector. As expected, the regions with the highest barriers to trade in financial services experience the biggest expansion in their financial sectors. These include the Philippines, Korea, Chile and Indonesia. Only the USA and the EU experience a slight fall in the output of their financial services sectors. In fact, these two regions experience a fall in the output of all sectors. This is a direct result of reallocating their capital from domestic sectors to other regions, in response to other regions' trade liberalisation. On the other hand, liberalising regions generally record positive growth in almost all other sectors. This result can be explained by the combination of three factors: the overall size of the financial services sector in their respective regional GDP, the importance of financial services as an intermediate input into the production of other goods and services, and the expansion of capital usage.

The share of financial services in world GDP is 13.9 per cent. Financial services also contribute to a larger proportion of GDP in all regions compared with telecommunications, with the largest relative differences being in the three largest investing regions, Japan, the USA and the EU. The average share of financial services in GDP in these three regions is 16.3 per cent. This high share causes a large proportion of the capital stock to be reallocated from these liberalised regions to liberalising regions. Such a large outflow of capital can only be accommodated by reducing the liberalised regions' domestic capital. This is observed in the results for both the USA and the EU. A similar result is not observed in Japan as its relatively high non-discriminatory barriers serve to constrain a substantial outflow of capital after trade liberalisation. Instead, the demand for capital by Japan actually increases, which encourages Japan to withdraw its FDI from abroad.

Another important effect explaining the sectoral results, especially in liberalising regions, is the importance of financial services as an intermediate input into production. The share-weighted average of financial services in total production costs for the world as a whole is 8.8 per cent. Thus, removing a given barrier in financial services will lead to a significant fall in the production costs and output prices of all sectors using them as their intermediate inputs and in their output prices. Sectoral outputs are expected to respond to the changes in their prices. 
The largest reductions in the price of financial services occur in the regions with the highest barriers to remove. As output prices in liberalising regions fall, the demand for their exports increases in liberalised regions. This helps drive the strong output expansion of both financial services and non-financial services sectors in liberalising regions, which requires increased capital in these sectors. Moreover, the rise in the real GNP in liberalising regions also pushes up their consumption of all goods and services, which provides another impetus for domestic output expansion.

Table 9 Projected effects on sectoral output of complete trade liberalisation in financial services (per cent)

\begin{tabular}{|c|c|c|c|c|c|c|c|c|}
\hline Region & $P r i^{a}$ & $\operatorname{Sec}^{\boldsymbol{b}}$ & $\operatorname{Con}^{c}$ & $T t_{-} \boldsymbol{d}$ & $\mathrm{Cm} n^{\boldsymbol{e}}$ & $F i b^{f}$ & Osr 9 & $D w e^{h}$ \\
\hline Australia & 0.15 & -0.09 & -0.16 & -0.05 & 0.00 & 0.04 & 0.04 & 0.01 \\
\hline New Zealand & 0.88 & 1.15 & 0.68 & 0.70 & 0.50 & 0.76 & 0.36 & 0.65 \\
\hline Japan & -0.61 & -0.90 & -0.43 & -0.74 & -0.61 & 2.06 & -0.93 & -0.72 \\
\hline Korea & -0.37 & 1.38 & 0.89 & 0.30 & 0.32 & 4.85 & -0.34 & -0.33 \\
\hline Indonesia & 0.61 & 4.82 & 1.84 & 2.12 & 1.50 & 3.81 & 1.55 & 1.17 \\
\hline Malaysia & -0.27 & 0.57 & 0.97 & 0.91 & 0.44 & 2.97 & 0.63 & 0.18 \\
\hline Philippines & 0.98 & 7.32 & 3.77 & 5.45 & 1.82 & 5.12 & 4.34 & 0.65 \\
\hline Singapore & 0.90 & 0.93 & 1.62 & 2.28 & 0.52 & 3.12 & 2.23 & -0.32 \\
\hline Thailand & 0.30 & 3.84 & 1.45 & 3.25 & 1.24 & 2.94 & 1.41 & 1.33 \\
\hline China & -0.37 & 0.46 & 0.82 & -0.16 & 0.16 & 3.31 & -0.12 & 0.27 \\
\hline Hong Kong & -0.34 & -1.17 & -1.53 & -0.13 & -0.17 & 0.63 & -0.30 & -0.50 \\
\hline Taiwan & 0.11 & 0.37 & -0.02 & -0.02 & 0.08 & 1.28 & -0.20 & -0.02 \\
\hline Canada & 0.18 & -0.07 & -0.29 & 0.02 & -0.01 & 0.16 & 0.02 & -0.13 \\
\hline USA & -0.05 & -0.36 & -0.45 & -0.14 & -0.10 & -0.05 & -0.02 & -0.19 \\
\hline Mexico & 0.96 & 3.83 & 0.88 & 1.76 & 1.21 & 1.79 & 0.99 & 1.64 \\
\hline Chile & 0.00 & -0.20 & 1.66 & 0.25 & 0.16 & 4.61 & 0.03 & -1.77 \\
\hline Rest of Cairns ${ }^{i}$ & 1.59 & 3.04 & 2.03 & 1.72 & 1.09 & 2.38 & 0.86 & 0.72 \\
\hline European Union & -0.04 & -0.31 & -0.42 & -0.16 & -0.06 & -0.02 & -0.01 & -0.08 \\
\hline Rest of Worldj & 0.09 & 0.61 & 0.32 & 0.31 & 0.23 & 0.77 & 0.24 & 0.05 \\
\hline World & 0.04 & 0.02 & -0.12 & -0.06 & -0.06 & 0.61 & -0.07 & -0.06 \\
\hline
\end{tabular}

$\mathbf{a}_{\text {Primary industries. }} \mathbf{b}_{\text {Secondary industries. }}{ }^{\mathbf{c}}$ Construction. ${ }^{\mathbf{d}}$ Trade and transport. ${ }^{\mathbf{e}}$ Telecommunications. ${ }^{\mathbf{f}}$ Financial services. ${ }^{\mathbf{g}}$ Other services.

$\mathbf{h}_{\text {Dwellings. }} \mathbf{i}$ This region consists of Argentina, Brazil, Colombia and Uruguay. $\mathbf{j}$ This region is almost entirely composed of non-APEC developing countries.

Source: FTAP2 model projections.

Similar to telecommunications liberalisation, the primary sector experiences the second largest output expansion when barriers to trade in financial services are removed. The effects of capital reallocation across regions cause the rates of return to sector-specific factors of production to diverge between liberalising and liberalised regions, with higher rates of return to fixed factors in the former and lower rates in the latter. These changes in rates of return cause the price of primary goods to fall in liberalised regions relative to liberalising regions. These changes in relative prices lead world demand for primary goods to shift from those produced by liberalising regions, to those produced by liberalised regions.

\section{Conclusion}

This paper presents a quantitative analysis of the possible effects on the regional and world economies of liberalising trade in two key services sectors, telecommunications and financial services, for which WTO members have undertaken commitments for trade liberalisation. As these commitments represent partial rather than complete liberalisation, by modelling the effects of complete liberalisation of these sectors, 
this study is intended to add impetus for further commitments for trade liberalisation in these sectors by WTO members.

The analysis shows that the results of trade liberalisation depend, to a large extent, on how trade barriers affect the regions and economies of the world. Barriers to trade in telecommunications and financial services are generally much higher in developing regions than in developed regions. Removing barriers to trade in telecommunications and financial services is projected to increase world real GNP by 0.1 and 0.09 per cent, respectively. Regions with relatively high barriers and, therefore significant scope to liberalise, gain most from liberalisation. Multilateral removal of barriers to trade in telecommunications and financial services affects liberalising regions by increasing domestic and foreign investment in the liberalising sector, increasing the degree of competition in the liberalising sector, and reducing the cost of intermediate inputs for other sectors using the output of the liberalising sector. Removing barriers to trade in telecommunications and financial services affects relatively liberalised regions by increasing outward FDI and income earned from FDI, and reducing the prices of imports from liberalising regions, and thus the cost of using these imports as intermediate inputs or final consumption goods.

The current model captures the comparative static gains from trade liberalisation. In reality, there are dynamic gains from trade liberalisation as well. In a dynamic setting, a rise in real GNP also increases savings, which can be used to finance future investment and the accumulation of capital. An increase in the capital stock leads to further growth in GNP. As such dynamic impacts are not captured in the results, the estimated gains from the liberalisation scenarios should be interpreted as the lower bounds of all the potential gains to regional and world economies. Identifying these static gains is important as it highlights the pattern of interregional distribution of gains from the proposed trade liberalisation scenarios. These static gains are important in the sense that they can trigger growth effects in a dynamic setting that, to a large extent, reinforces the initial static gains. To capture such dynamic effects, further work is needed to extend the model to incorporate some key dynamic features, such as investment behaviour and capital accumulation.

Another area for future development is the database. The results presented in this study partly depend on the reliability of the output shares used to disaggregate the financial services sector. As the information on regional services sectors is limited, the disaggregation is based on stylised facts rather than detailed sectoral data. In future work, these shares should be drawn from regional input-output tables with the necessary sectoral detail for all services sectors including those already examined here. Furthermore, with greater sectoral detail it will be possible to extend the current analytical framework to estimate trade liberalisation in other services sectors as well, such as wholesale and retail trade, business services, health, education, maritime transport and electricity.

\section{References}

APEC (Asia-Pacific Economic Cooperation) 1995, Foreign Direct Investment and APEC Economic Integration, APEC Publication No. 95-EC-01.1, Singapore.

Brown, D.K., Deardorff, A.V., Fox, A.K. and Stern, R.M. 1995, 'Computational analysis of goods and services liberalisation in the Uruguay Round', in Martin, W. and Winters, L.A. (eds), The Uruguay Round and the Developing Economies, Cambridge University Press, Cambridge, pp. 365-80.

Dee, P. and Hanslow, K. 2000, Multilateral Liberalisation of Services Trade, Staff Research Paper, Productivity Commission, Canberra. 
Francois, J.F., McDonald, B. and Nordstrom, H. 1996, 'The Uruguay Round: A numerically based qualitative assessment', in Martin, W. and Winters, L.A. (eds), The Uruguay Round and the Developing Economies, Cambridge University Press, Cambridge, pp. 253-91.

Hanslow, K., Phamduc, T. and Verikios, G. 1999, The Structure of the FTAP Model, Research Memorandum MC58, Productivity Commission, Canberra.

Harrison, J.W. and Pearson, K.R. 1996, 'Computing solutions for large general equilibrium models using GEMPACK’, Computational Economics, vol. 9, no. 2, pp. 83-127.

Hertel, T.W. 1999, Potential gains from reducing trade barriers in manufacturing, services and agriculture, paper presented at the $24^{\text {th }}$ Annual Economic Policy Conference, Federal Reserve Bank of St. Louis, 21-22 October.

Hertel, T.W., Anderson, K., Francois, J.F. and Martin, W. 1999, Agricultural and non-agricultural liberalization in the Millennium Round, paper presented at the Global Conference on Agriculture and the New Trade Agenda from a Development Perspective: Interest and Options in the WTO 2000 Negotiations, World Bank and WTO, Geneva, 12 October.

Huff, K. and Hertel, T.W. 1996, Decomposing Welfare Changes in GTAP, GTAP Technical Paper No. 5, Center for Global Trade Analysis, Purdue University, West Lafayette.

Kalirajan, K., McGuire, G., Nguyen-Hong, D. and Schuele, M. 1999, The price impact of restrictions on banking services, paper presented at the Trade Policy Forum of the Pacific Economic Cooperation Council, Auckland, 3-4 June.

Malcolm, G. 1998, Adjusting Tax Rates in the GTAP Data Base, GTAP Technical Paper No. 12, Center for Global Trade Analysis, Purdue University, West Lafayette.

Markusen, J., Rutherford, T.F. and Tarr, D. 1999, 'Foreign direct investment in services and the domestic market for expertise', paper presented at the Second Annual Conference on Global Economic Analysis, Gl. Avernaes, Denmark, 20-22 June.

McKibbin, W.J. 1999, 'International capital flows, financial reform and consequences of changing risk perceptions in APEC economies', paper presented at the conference Experiences of Economic Reform Within APEC, 12-14 July, Wellington.

Petri, P.A. 1997, 'Foreign direct investment in a computable general equilibrium framework', paper presented at the conference Making APEC work: Economic Challenges and Policy Alternatives, 13-14 March, Keio University, Tokyo.

The Secretariat of the Council for Trade in Services 1999, Recent developments in services trade - Overview and assessment, Background Note S/C/W/94, Geneva, http://www.wto.org/english/tratop_e/serv_e/w94.doc (accessed 3 June 2000).

United Nations (UN) 1999, World Investment Report 1999: Foreign Direct Investment and the Challenge of Development, Geneva.

Verikios, G. and Hanslow, K. 1999, 'Modelling the effects of implementing the Uruguay Round: A comparison using the GTAP model under alternative treatments of international capital mobility', paper presented at the Second Annual Conference on Global Economic Analysis, Gl. Avernaes, Denmark, 20-22 June.

Verikios, G. and Zhang, X-G. 2001, FTAP2: Theory and Data, Research Memorandum, Productivity Commission, Canberra (in press).

Warren, T. 1999, 'The impact on output of impediments to trade and investment in telecommunications services', in Findlay, C. and Warren, T. (eds) 2000, Impediments to Trade in Services: Measurement and Policy Implications, Routledge, London.

WTO Secretariat, 1999, An introduction to the GATS, WTO, Geneva, http://www.wto.org/english/tratop_e/serv_e/gsintr_e.doc, (accessed 3 June 2000). 